\title{
URGENSI PENDIDIKAN SIFAT MALU DALAM HADITS \\ (Telaah Hadits Imran Ibn Husain tentang Sifat Malu dalam Kitab Musnad Ahmad Ibn Hanbal)
}

\author{
Dr. Supian Sauri, Lc., M. Ag. \\ Dosen Universitas Islam Sultan Agung (UNISSULA) - Semarang \\ supiansauri@unissula.ac.id
}

\begin{abstract}
In the hadith of the Prophet explained one of the attributes called the term albaya'. The nature of al-haya 'is translated in Indonesian with the meaning of shame. Most people assume the nature of shame is a bad trait that should be kept away from someone's personal. But the shame is actually recommended by the Prophet because it is a good quality as stipulated in the hadith of Imran Ibn Husain, narrated by Ahmad Ibn Hanbal. This study aims to provide an explanation of the nature of shame mentioned by the Prophet as one of the good qualities. The conclusion of this study is the answer for people who still have the notion that shame is a bad trait that must be abandoned. The nature of shame is very urgent in Islamic education that should be fostered by all Muslims. That is due to the nature of shame can contribute to education, among others: 1) Education in shame can foster human ability to maintain the mind; 2) Keeping away actions that consume things that are prohibited; 3) Always remember death; 4) Become a person who is zuhud; 5) Contribute to the education of faith; 6) Education to decorate and beautify yourself with commendable qualities namely shame; 7) Human education to achieve the love of Allah.
\end{abstract}

Keywords: Hadith, Prophet, Imran, Embarrassed, Education

\begin{abstract}
ABSTRAK
Dalam hadits Nabi Saw dijelaskan salah satu sifat yang disebut dengan istilah alhaya'. Sifat al-haya diterjemahkan dalam bahasa Indonesia dengan arti malu. Kebanyakan orang mengangap sifat malu merupakan sifat buruk yang seharusnya dijauhkan dari peribadi seseorang. Namun sifat malu tersebut justru dianjurkan oleh Nabi Saw sebab merupakan sifat yang baik sebagaimana termaktub dalam hadits Imran Ibn Husain yang diriwayatkan Ahmad Ibn Hanbal. Penelitian ini bertujuan untuk memberikan penjelasan hakikat sifat malu yang disebutkan Nabi Saw sebagai salah satu sifat yang baik. Kesimpulan penelitian ini adalah jawaban untuk orang-orang yang masih memiliki anggapan bahwa malu adalah sifat buruk yang mesti ditinggalkan. Sifat malu sangat urgen dalam pendidikan Islam yang semestinya dipupuk oleh semua kaum muslim. Hal itu disebabkan sifat malu dapat berkontribusi dalam pendidikan antara lain: 1) Pendidikan malu dapat memupuk kemampuan manusia dalam menjaga akal pikiran; 2) Menjauhkan perbuatan untuk mengonsumsi hal-hal yang dilarang; 3) Selalu mengingat kematian; 4) Menjadi peribadi yang zubud; 5) Berkontribusi dalam pendidikan iman; 6) Pendidikan untuk menghias dan mempercantik diri dengan sifat terpuji yaitu malu; 7) Pendidikan manusia untuk mencapai cinta Allah Swt.
\end{abstract}

Kata kunci: Hadits, Nabi, Imran, Malu, Pendidikan 


\section{A. PENDAHULUAN}

Pendidikan adalah salah satu faktor yang menetukan arah suatu umat dan bangsa ke depan. Nabi Saw mengajarkan keutamaan pendidikan dalam berbagai persoalan, dari masalah yang kecil hingga besar. Salman al-Farisi saat ditanya oleh orang kafir tentang pelajaran yang diajarkan Nabi Saw kepada kaum muslimin, dengan bangganya ia menjawab dengan berkata bahwa Nabi Saw telah mengajarkan segala urusan kepada umatnya hingga urusan yang terkait bersuci (Ibn AlHajjaj, tth: 223). Pernyataaan Salman ini menegaskan visi Nabi Saw bagi umatnya ke depan agar menyiapkan pendidikan dengan sebaik-baiknya. Pendidikan tersebut adalah pendidikan paripurna yang menyentuh segala aspek kehidupan manusia.

Realita masyarakat tidak bisa dipisahkan dari masalah pendidikan. Maraknya pemberitaan LGBT yang menggambarkan pandangan seksual manusia yang menyimpang menyebabkan orang tua resah (Ermayani, 2017). Ditambah lagi peredaran obatobatan terlarang dan upaya legalitas minumana keras oleh sebagian pihak dan termasuk kemungkianan untuk menasionalkan minuman bisa terjadi. Pemberitaaan ini makin menambah beban tanggung jawab semua pihak dalam mendidik anak-anak yang dijadikan Allah Swt sebagai amanah bagi orang tuanya. Pendidikan adalah tanggung jawab keluarga dan masyarakat. Maka, sudah seharusnya jika pihak-pihak terkait memiliki strategi yang tepat dalam menghadapi ancaman-ancaman tersebut.

Salah satu strategi dalam membentengi pendidikan anak sebagai generasi masa depan adalah pendidikan akhlak (Al-Jurjani, 1403: 101).
Pendidikan akhlak kepada anak diajarkan melalui latihan-latihan yang terpadu yang membimbing mereka dalam setiap langkahnya. Suatu pepatah menyatakan 'setiap perkataan itu memiliki maqam tersendiri', demikian pula sebaliknya. Berdasar pepatah ini, setiap anak yang berada dalam lingkungan pendidikan kondusif yang berpijak pada pendidikan akhlak akan terlatih untuk bersikap bijak dan tepat. Ia akan menyaring informasi yang didapatnya dengan latihan-latihan yang sudah dia lakukan di lingkungannya, di rumah maupun di luar rumah. Pergaulan-pergaulan yang menyimpang akan mudah ditangkalnya sehingga orang tua tidak kahwatir terhadap keberadaannya.

Perilaku menyimpang seperti LGBT, konsumsi minuman keras, dan kenakalan remaja lainnya pada dasarnya disebabkan pendidikan akhlak kurang mengena. Pengajaran pendidikan akhlak yang baik di dalam rumah akan memberikan efek posistif kepada anakanak dalam menjalani kehidupan. Kondisinya akan semakin baik apabila anak tersebut dididik dalam suatu lingkungan yang menitik beratkan pendidikan akhlak. Anak diajarkan tata cara pergaulan yang baik sesama teman yang terdiri dari laki-laki dan perempuan. Juga diajarkan cara berpakaian sesuai aturan agama. Dengan demikian ia anak laki-laki akan mengetahui bahwa memakai pakaian yang dipakai perempuan adalah terlarang baginya dan demikian pula sebaliknya (Ibn Hanbal, tth: 243). Norma-norma lainnya yang dalam lingkungan tersebut menyebabkan anak mengetahui dan memilah teman yang baik dan buruk. Maka, dengan model pendidikan seperti ini anak tidak akan mudah terpengaruh pihak luar 
dalam sikap, kebiasaaan dan pergaulan lainnya.

Pendidikan akhlak yang diajarkan Nabi Saw banyak ragamnya. Ajaran Rasulullah telah memberikan petunjuk dan arahan terbaik kepada kehidupan manusia yang tidak bisa dilepaskan dari hubungan vertikal dan horizontal. Kedua hubungan itu dalam pendidikan ala Nabi Saw harus selaras dan sejalan dengan kebahagian yang hakiki yaitu kebahagian dunia dan akhirat. Pendidikan akhlak Nabi Saw ini di antaranya adalah pendidikan malu, yang dalam hadits disebut al-haya'. Kata ini selanjutnya diterjemahkan dalam bahasa Indonesia sebagai "malu”.

Sebagian orang menganggap bahwa malu adalah sifat buruk yang harus dijauhi. Orang yang pemalu selalu dipersepsikan tidak baik dan kurang gaul. Orang-orang terdekatnya akan selalu mengingatkan agar ia meninggalkan sifat tersebut. Anak yang tidak berani berjoged di hadapan kawan-kawannya akan dicemoohkan sebagai anak kampungan dan tidak mengerti pergaulan anak muda. Namun, berbeda terbalik perlakuannya kepada orangorang seumuran yang tidak berangkat ke masjid untuk salat berjamaah dan tidak pergi ke tempat pengajian. Tindakan itu akan dianggap lumrah dan wajar terjadi di kalangan anak muda oleh sebagian orang. Sekalipun mereka melihat dan menyaksikan keburukan tersebut, mereka akan enggan mengingatkannya. Bahkan bisa saja mereka akan mengatakan suatu alasan kepada orangorang karena dia malu untuk mengingatkannya .

Fenomena seperti ini sering terjadi di masyarakat yang pada umumnya tidak mengerti batasanbatasan malu. Kebenaran yang semestinya dilaksanakan kerap ditinggalkan. Sementara yang buruk mereka tak segan melakukannya sekalipun akan merugikan manusia secara individu maupun sosial. Mengonsumsi minuman keras yang jelas berbahaya dan merusak tubuh sering tidak diindahkan. Memakai pakaian yang minim yang tidak menutup aurat dianggap sebagai trend masa kini serta alasan-alasan lainnya meski hal itu bertentangan dengan norma-norma yang berlaku di masyarakat.

Batasan-batasan malu yang masih rancu, menyebabkan kaum muslimin kurang menyadari ajaran Nabi Saw tentang sifat malu yang disebut sebagai al-haya'. Dalam hadits Imran Ibn Husain, secara gambalang Nabi Saw menjelaskan bahwa malu merupakan sifat yang baik. Tidaklah seorang itu memiliki malu kecuali ia akan memiliki kebaikan dan kesalihan yang dapat membawa umat manusia menjadi umat beradab.

Hadits Imran Ibn Husain yang menjelaskan sifat malu ini adalah:

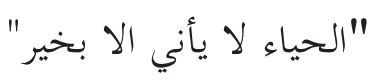

"Sifat malu tidak akan mendatangkan apa-apa kecuali suatu kebaikan.” (Ibn Hanbal, 2001: 54).

Berlandaskan hadits tersebut, Nabi Saw menempatkan sifat malu sebagai salah satu sifat mulia yang semestinya dimiliki setiap orang. Setiap orang yang memiliki sifat malu akan didorong melakukan hal-hal positif dalam segala tindakannya. Hadits Imran Ibn Husain sendiri mendapatkan dukungan dari hadits lain yang 
menempatkan sifat malu sebagai salah satu dari iman.

Penjelasan Nabi Saw terkait sfat malu semestinya bisa diterapkan dalam sistem pendidikan umat. Fenomena masyarakat yang terjangkit berbagai macam tindakan-tindakan amoral salah satunya disebabkan oleh lemahnya pendidikan tentang malu. Secara umum masyarakat mengetahui keruntuhan nilai-nilai umat saat ini sangat drastis. Demikian pula tata kesopanan dan budi pekerti mulai terkikis disebabkan umat belum tercerahkan oleh pendidikan yang tepat.

Sekitar tahun 1980-an, jarang ditemukan murid sekolah berani melakukan perbuatan yang dianggap tidak sopan kepada gurunya. Bahkan pada masa itu seorang murid akan sembunyi apabila bertemu gurunya karena malu. Mereka juga berusaha menjauh dari pandangan gurunya pada saat sedang bermain di jalan atau di lapangan. Padahal waktu tersebut semestinya dimanfaatkan untuk belajar di rumah atau belajar kelompok bersama teman-teman lain.

Di kelas, murid akan memperhatikan pelajaran yang disampaikan guru, demikian pula di luar kelas. Seperti yang dilakukan guru dalam mengingatkan tugas atau pekerjaan rumah kepada murid agar dikerjakan di rumah bersama orang tua atau saudaranya tentang materi yang telah dipelajari. Mulai sore hari anak yang mendapatkan tugas tersebut sampai malam akan memperhatikan kewajibannya untuk dikerjakan yang selanjutnya akan dikoreksi oleh guru. Bahkan jika tugas gurunya tidak dikerjakan, murid itu harus rela diingatkan dan dihukum di depan kelas. Ketegasan guru terhadap murid yang melalaikan tugas mengingatkannya agar lebih tanggung jawab pada waktu lain dan tidak mengulangi kesalahan kembali.

Di masa dulu, seorang murid akan malu jika tidak beretika dalam kelas. Saat guru meminta murid untuk memotong kuku atau memotong rambut maka dengan senang hati murid akan mematuhi apa yang diperintahkan. Tentunya, murid yang tidak mematuhi perintah guru akan dingatkan guru dan teman-teman lain.

Akibat tidak dipupuknya pendidikan malu kenakalan murid kepada guru sering terdengar dan disaksikan melalui media televisi atau media sosial. Dari sinilah guru dan orang tua murid perlu merenungkan mengapa sebagian murid-murid sekarang ini dikabarkan melakukan perbuatanperbuatan yang bertentangan dengan etika. Bukan hanya sebatas kata-kata, bahkan sebagian murid tersebut sudah berani melakukan tindakan kekerasan yang dapat melukai gurunya.

Pendidikan malu hendaknya dimulai dalam keluarga, sebab sifat-sifat seorang anak muncul dan berkembang dalam lingkungan ini. Orang tua perlu mengenalkan dan menekankan nilai-nilai akhlak yang baik kepada anak-anaknya. Dari pengenalan akhlak yang baik, anak akan malu melakukan perbuatanperbuatan yang bertentangan dengan etika yang semestinya. Jika hal ini tidak dilakukan, dapat menimbulkan kasuskasus yang melibatkan anak dengan orang tuanya, seperti kasus pembunuhan anak kepada orang tuanya atau pidana lain akibat orangtua tidak dapat memenuhi kebutuhan anak. Bahkan sebagian anak berani memenjarakan orang tuanya yang sudah berumur karena masalah sepele dimana ia 
mengangap orang tuanya sendiri telah mengambil hak anak.

Dari sinilah fenomena kelam dalam masyarakat dapat diketahui disebabkan minimnya kualitas pendidikan saat ini. Pendidikan bukan hanya sekedar transfer ilmu pengetahuan saja. Namun pendidikan yang utama adalah mendidik manusia menjadi manusia yang bermartabat dengan akhlak mulia seperti yang diajarkan Nabi Saw. Akhlak dalam Islam ditempatkan sebagai ajaran utama dan mendasar dalam syariat yang dibawanya. Nabi Saw menyebutkan hal dalam haditsnya:

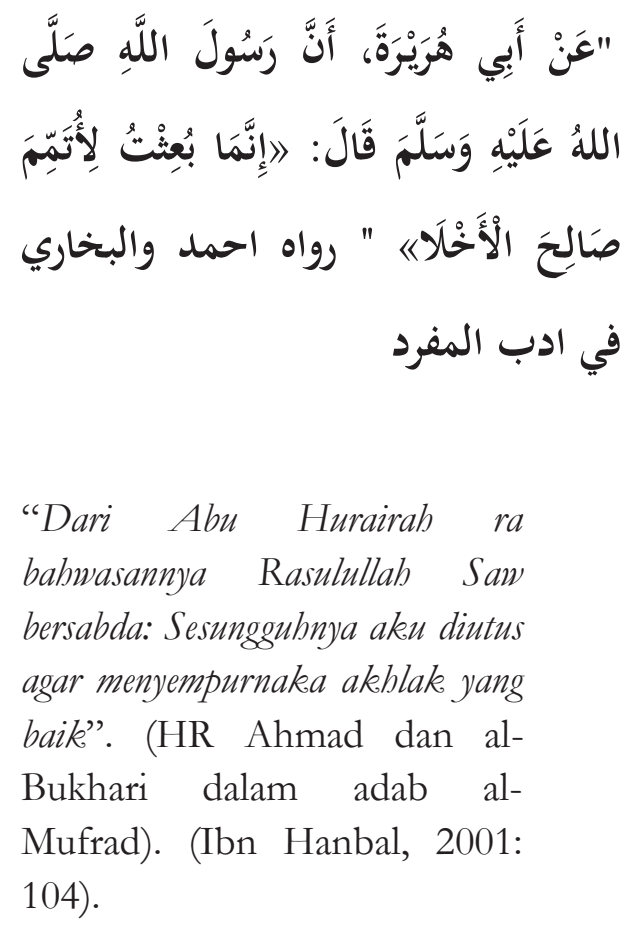

Pada hadits tersebut Nabi Saw menempatkan pendidikan akhlak sebagai misi yang diembannya dalam dakwah. Dengan demikian maka, pendidikan akhlak tidak bisa dijauhkan dari pendidikan yang ada, baik secara formal maupun non formal.

Dalam pendidikan, sifat malu sebagaimana disebutkan dalam hadits
Imran Ibn Husain, akan mendatangkan hal-hal postif. Tidak ada kebaikan pada suatu kaum kecuali unsur sifat malu tersebut akan selalu melekat pada kaum tersebut. Demikian pula sebaliknya, keburukan akan menyebar dan menjalar dalam suatu kaum jika sifat malu tidak ada pada mereka. Oleh karena itu penjelasan sifat malu yang dijelaskan Nabi Saw tersebut perlu ditulusuri. Bisa jadi, dekadensi yang terjadi dalam etika umat hari ini disebabkan tidak mengerti maksud sabda Nabi Saw tentang malu.

\section{B. PEMBAHASAN}

\section{Pengertian Sifat Malu}

Malu dalam bahasa Arab disebut al-haya' atau istibya yang secara etimologi adalah masdar dari bayiya - yahya - bayah yang berarti hidup. Orang tangguh dalam hidupnya tangguh dipastikan memiliki sifat malu disebabkan kemampuan dirinya dalam mengatahui hal-hal yang buruk. Selain dari ketangguhannya tersebut, sifat malu juga dapat berasal dari kekuatan panca indera seorang manusia dan kelembutannya (anNawawi, 1415H: 1). Pengertian secara etimologi ini menjelaskan sifat baya yang memiliki fungsi mendorong manusia menjadi manusia yang paripurna dan utuh. Sementara manusia yang tidak memilki sifat haya, ia akan menjadi manusia yang hampa seakan-akan ruh yang pada dirinya dicabut Allah dan akhirnya mati tak berarti (AlJauziyyah: 1416H: 248) (AlMuqaddam, 1436H: 5-6). Malu secara bahasa juga dapat diartikan alimtina' yang berari menahan atau 
mencegah dan al-Inqibad yang berati menutup diri. Oleh karaena itu, manusia yang memiliki sifat malu adalah manusia yang mampu menahan dan menutup diri dari halhal yang akan mendatangkan aib pada dirinya (Al-Asqalani, tth: 521).

Secara terminologi malu didefinisikan oleh ulama dengan beberapa pengertaian. Antara lain:

1) Malu adalah keadaan manusia yang penyebabnya berasal dari kehawatiran terungkap suatu aib pada dirinya dan cacian (Al Muqaddam, 1436H: 5).

2) Malu adalah salah satu akhlak yang dapat memdorong manusia menjauhi perkataan dan perbuatan yang buruk dan mencegah diri dari sikap acuh terhadap hak orang lain (AlJauziyyah, 1416H: 249).

3) Malu adalah menjauhi keburukan akibat dari kekhawatiran akan mendapat cacian orang lain (AlMuqaddam, 1436H: 7).

4) Malu adalah kewaspadaan yang menyebabkan manusia menutup diri dari segala karena cacian orang lain (Al-Muqaddam, 1436H: 7)

5) Malu adalah sesuatu yang tertanam pada jiwa yang mengakibatkan manusia menunaikan segala tugas, menjalian silturahim dan berbakti kepada orang tua (Asy-Syafi'i, 1425H: 150).

6) Malu adalah suatu sifat yang maknanya sama dengan waqar (kehati-hatian) dan menjaga diri dari mengatakan sesuatu yang dapat mempermalukan orang lain (Al-Jauziyah, 1416: 249).
7) Malu adalah melihat nikmat yang diberikan Allah swt dan menyadari kekurangan diri (AlBukhari, 1422H: 29).

Dari pengertian secara terminologi, kedudukan sifat malu pada manusia sangat diperlukan. Manusia dalam kehidupannya memerlukan batasan-batasan yang mengatur tingkah lakunya dalam berhubungan secara vertikal dengan Allah Swt dan berhubungan secara horizontal dengan sesama makhluk. Pada prinsipnya manusia hendaknya mengenal posisinya sebagai makhluk ciptaan Allah Swt dan sekutu makhluk lainnya. Maka dengan sifat malu, manausia akan selalu takut melakaukan hal-hal yang merugikan dirinya karena kesalahannya kepada Allah Swt dan kesalahan kepada sesama manusia lainnya.

\section{Hadits-hadits Imran Ibn Husain tentang Malu}

1) Hadits Imran Ibn Husain dari jalur Yahya Ibn Sa'id, dari Khalid Ibn Rabbah dari Abu Sawwar dari Imran Ibn Husain dari Nabi Saw.

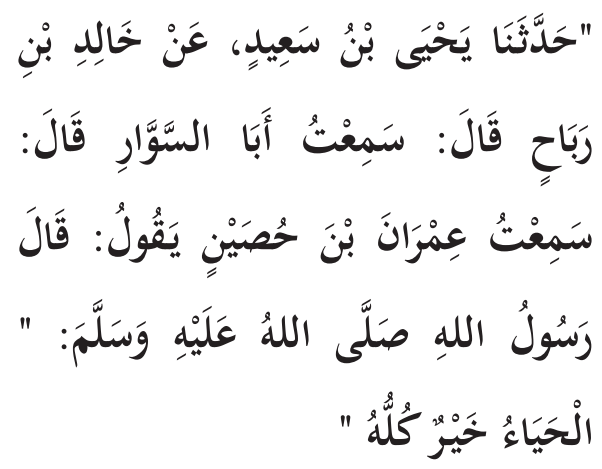

"Yabya Ibn Sai'd telah menyampaikan hadits kepada kami dari Khalid Ibn Rabbah. Ia berkata aku mendengar 
Abu Sawwar berkata: aku mendengar Imran Ibn Husain berkata: Rasulullab Saw bersabda: semua sifat malu itu adalah baik" (HR Ahmad). (Ibn Hanbal, 2001: 51).

2) Hadits Imran Ibn Husain dari jalur Muhammad Ibn Ja'far dari Syu'bah dari Qatadah dari Abu Sawwar.

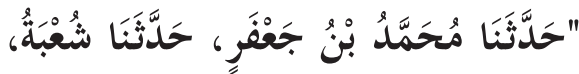
عَنْ قَتَادَةَ قَالَ: سَمِعْتُ أَبَا السَّوَّارِ

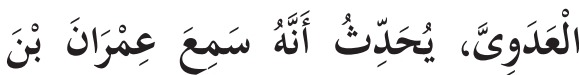
حُصَيْنٍ الْخُخَاعِيَّ يُحَدِّثُ، عَنْ رَسُولِ

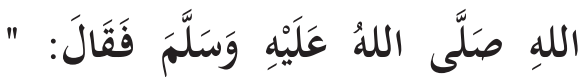

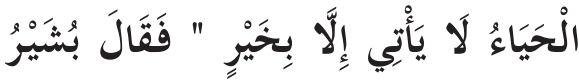

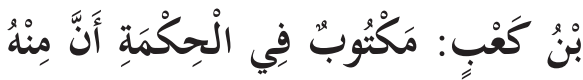

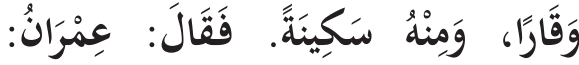

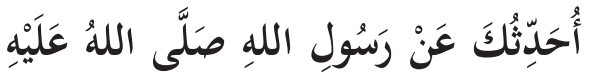

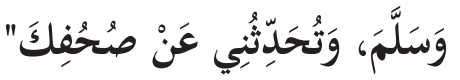

'Mubammad Ibn Ja'far telah menyampaikan hadits pada kami, Syu'bah telah menyampaikan badits kepada kami dari Qatadah, berkata: Aku mendengar Abu Sawwar al-Adawi menyampaikan hadits kepada kami. Babwasannya ia mendengar Imran Ibn Husain al-Khuzai' memperoleh hadits dari Rasullab Saw: Malu adalah sifat yang tidak akan menghasilkan apa-apa kecuali kebaikan semata. Kemudian Busyair Ibn Ka'ab berkata: Termakatub dalam al-bikmah, sesunggubnya pada sifat malu itu ada kehat-hatian dan ketenangan. Kemudian Imran Ibn Husain berkata: aku menyampiakan hadits kepadamu dari Rasulullah Saw sementara kamu menceritakan sesuatu kepadaku dari lembaran-lembaran bukumu". (HR Ahmad). (Ibn Hanbal, 2001: 54).

3) Hadits Imran Ibn Husain dari jalur Yazid dari Khalid Ibn Rabbah Abu al-Fadhl dari Abu Sawwar al-Adawi dari Imran Ibn Husain dari Nabi Saw.

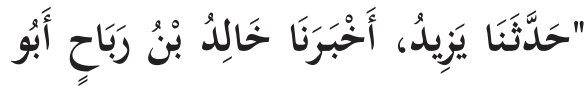

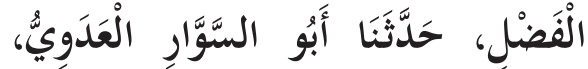

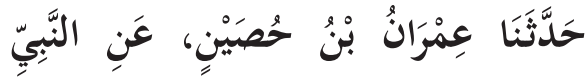

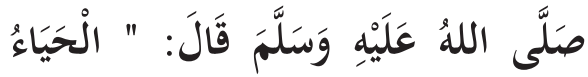

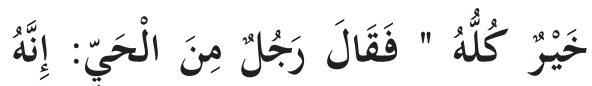

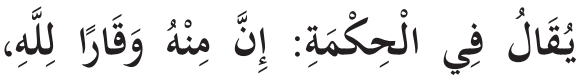

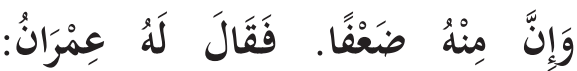

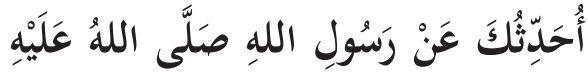

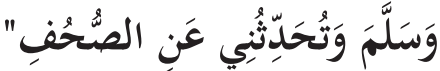

"Yazid telab menyampaikan hadits kepada Kami, Khalid Ibn Rabbah Abu Faddal telah mengabarkan hadits kepada kami, Abu as-Sawwar alAdawi telah menyampaikan hadits kepada Kami, Imran Ibn Husain telah menyampaikan hadits kepada kami dari Nabi Saw: Selurub sifat malu itu adalah baik. Kemudian seorang laki-laki dari dari Kabilah al-Hayy berkata: sesunggubnya dalam al-bikmah disebutkan, bahwasannya sifat malu 
dapat menimbulkan kehati-hatian karena Allah dan darinya pula dapat menimbulkan kelemahan. Setelab mendengar itu, Imran berkata kepadanya: aku menyampaikan hadits Rasulullah kepada kamu malahan kamu sendiri menyampaikan suatu perkataan kepadaku yang bersumber dari lembaran-lembaran buku" (HR Ahmad) (Ibn Hanbal, 2001: 144).

4) Hadits Imran dari Jalur Affan dari Hamad dari Sabit dari Imran Ibn Husain dari Nabi Saw.

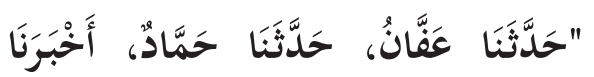

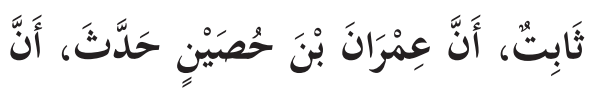
رَسُولَ اللهِ صَلَّى اللهُ عَلَيْهِه وَسَلَّمَ قَالَ:

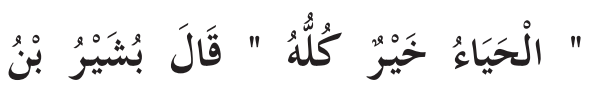
كَعْبِ: إِنَّ مِنْهُ ضَعْفًَا. فَغَضِبَبَ عِمْرَانُ

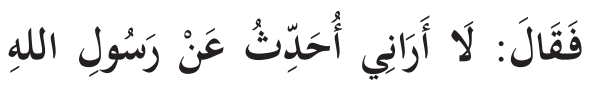

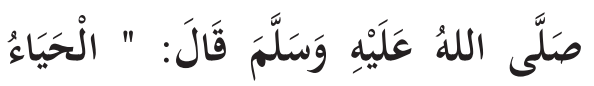

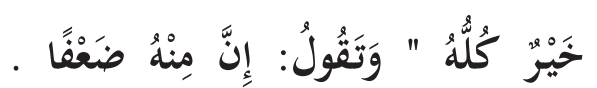

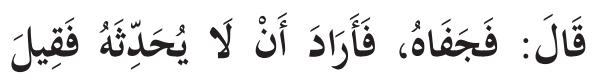

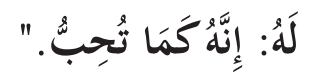

"Affan telah menyampaikan hadits kepada kami, Hammad telah menyampaikan hadits kepada kami, Sabit telah meberitakan hadits kepada kami. Sesunggubnya Imran Ibn Husain telah menyampaikan hadits: babwasannya Rasulullah Saw bersabda: seluruh sifat malu itu adalah baik. Busyair Ibn Ka'ab berkata: sesungguhnya sifat malu itu dapat menimbulkan kelemahan.

Mendengarkan demikian Imran marah dan berkata: aku tidak mimpi melihat Rasulullah menyampaikan badits. Beliau bersabda: semua sifat malu itu adalah baik sementara kamu mengatakan bahwasanya sebagian sifat malu itu dapat menimbulkan kelemahan. Berkata (Sabit): Kemudian Imran mengusirnya dan tidak ingin berbicara dengannya. Oleb karena itu dikatakan kepadanya: sesunggubnya (sifat malu) itu seperti yang kamu sukai". (HR Ahmad). “(Ibn Hanbal, 2001: 175)

5) Hadits Imran Ibn Husain dari jalur Yazid Ibn Harun dari abu Na'amah al-Adawi dari Humaid Ibn Hilal dari Busyair Ibn Ka'ab dari Imran Ibn Husain dari Nabi Saw.

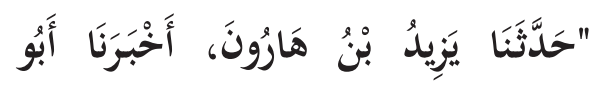

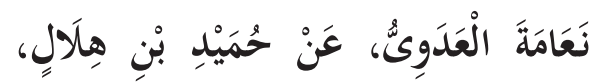
عَنْ بُشَيْرِ بْنِ كَعْبِ، عَنْ عِمْرَانَ بْنِ

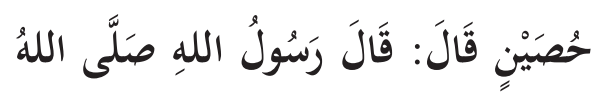

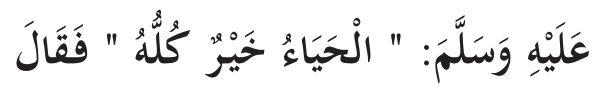

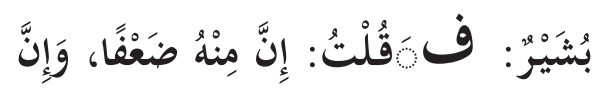
مِنْهُ عَجْزًا. فَقَالَ: أُحَدُِّكَكَ عَنْ رَسُولِ

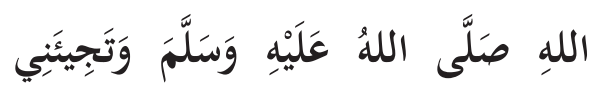

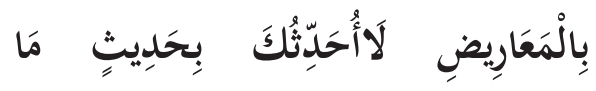

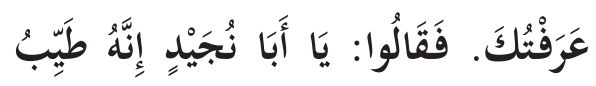

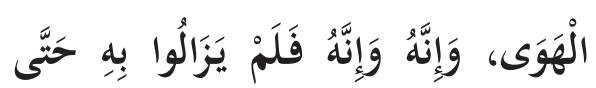

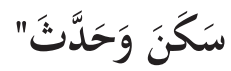


"Yazid Ibn Harun menyampaikan hadits kepada kami, Abu Na'amab alAdawi ,memberitakan hadits kepada kami dari Humaid Ibn Hilal dari Busyair Ibn Ka'ab dari Imran Ibn Husain. Ia berkata: Rasulullah Saw telah bersabda: " semua sifat malu itu adalah baik. Kemudian Busyair berkata: sesunggubnya sifat malu dapat menimbulkan kelemahan dan ketidakmampuan. Mendengar demikian, Imran Husain berkata: Aku menyampaikan suatu hadits kepadamu dari Rasulullah Saw. Sementara kamu malah mendatangkan perkara-perkara yang bertolak belakang. Aku tidak akan membicarakan suatu hadits lagi kepadamu. Aku tidak mengenal kamu. Karena itu, orang-orang berkata: wahai Abu Nujaid. Sesungguhnya dia itu adalah orang yang baik bati. Sesunggubnya dia itu orang yang baik hati. Sesunggubnya dia itu orang yang baik. Mereka terus mengulang-ulang bingga (Imran) tenang dan berbicara." (Ibn Hanbal, 2001: 183).

6) Hadits Imran Ibn Husain dari Rauh dari Abu $\mathrm{Na}$ 'amah al-Adawi dari Abu Sawwar dari Imran Ibn Husain dari Nabi Saw.

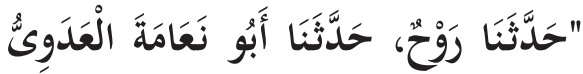

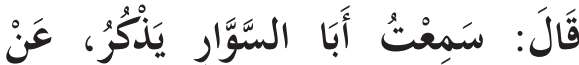

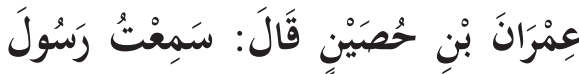

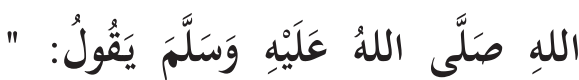

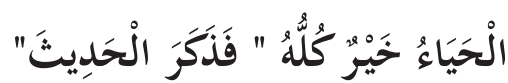

"Rauh telah menyampaikan hadits kepada kami, Abu Na'mah al-Adawi menyampaiakan hadits kepada kami. Ia berkata: aku mendengar Abu asSawwar menurutrkan hadits dari Imran Ibn Husain. Ia berkata: aku mendengar Rasulullab Saw bersabda: Semua sifat malu itu adalab baik. Kemudian Raub menuturkan hadits secara lengkap". (HR Ahmad). (Ibn Hanbal, 2001: 187).

7) Hadits Imran Ibn Husain dari jalur Ishaq Ibn Isa dari Hamad Ibn Yazid dari Ishaq Ibn Suwaid dari Abu Qatadah al-Adawi dari Imran Ibn Husain dari Nabi Saw.

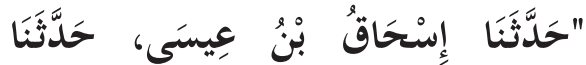
حَمَّادٌ يَعْني ابْنَ زيَّدِ، عَنْ إِسْحَاقَ بْنِ سُوَيْدِ، عَنْ أَبِي قَتََادَةَ الْعَدَوِيّ قَالَ: دَخَلْنَا عَلَى عِمْرَانَ بْنِ حُصَيْنِ فِي رَفْطٍ مِنْ بَني عَدِيٍّ فِينَا بُشَيْرُ بْنُ كَفْبٍ فَحَدَّتَنَا عِمْرَانُ بْنُ حُصَيْين قَالَ: قََلَ رَسُولُ اللهِ صَلَّلى اللهُ عَلَيِْْ وَسَتَّمَ: " الْحَيَاءُ خَيْرِ كُلَّهُ " أَوْ " إنَّ الْحَيَّاءَ خَيْرِ

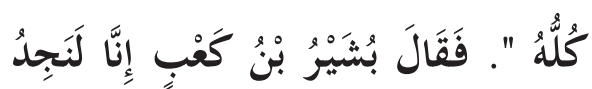

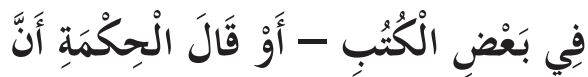

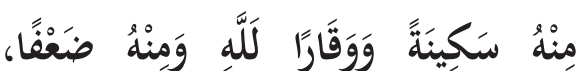
فَأَعَادَ عِمْرَانُ الْحَدِيثَ، وَأَعَادَ بُشَشَيْرِ

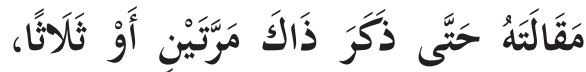


فَغَضِبَ عِمْرَانُ حَتَّى احمََرَّتُ عَيْنَاهُ

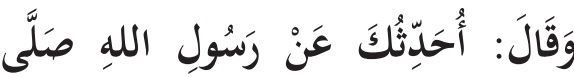

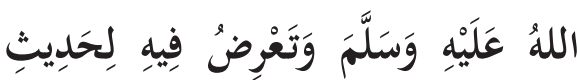

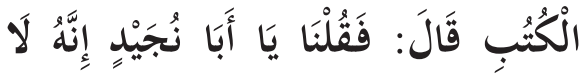

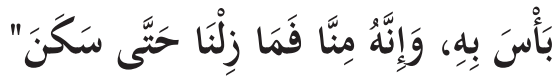

"Ishak Ibn Isa menyampaikan hadits kepada kami, Hammad Ibn Zaid menyampaikan hadits kepada kami dari Ishake Ibn Suwaid dari Abu Qatadab al-Adawi. Ia berkata: kami masuk ke Imran Ibn Husain yang sedang berada di suatu kelompok. Bani Adiy. Di antara kami yang datang adalab Busyair Ibn Ka'ab. Maka Imran Ibn Husain meyampaikan hadits kepada kami. Ia berkata: telah bersabda Rasulullah Saw: Semua sifat malu itu adalab baik atan sesunggubnya selurub sifat malu itu adalah baik. Kemudian Busyair Ibn Ka'ab berkata: sesunggubnya kami menemukan pada sebagian kitab atau beliau berkata dalam bikmah. Sesunggubnya sifat malu dapat menimbulkan ketenagan, ketenteraman karena Allah dan dapat menibulkan kelemahan. Mendengarkan demikaian, maka Imran mengulangi hadits. Dan Busyair mengulangi perkataannya bingga kali dua atau tiga. Oleh Karena itu, maka marablah Imran Ibn Husain sampai dua matanya memerah dan berkata: Aku menyamapaikan badits kepada kamu dari Rasulullab Saw dan kamu sendiri menandinginya karena suatu perkataan dari buku-buku tersebut. Abu Qatadah berkata: maka kami berkata: wahai Abu Nujaid sesunggubnya dia (Busyair) itu tidak. menjadi masalah apa-apa. Dan sesunggubnya dia itu bagian dari kami.
Kemudian kami berusaba terus menerus berkata bingga dia (Imran) menjadi tenag kembali". (HR Ahmad). (Ibn Hanbal, 2001: 203).

8) Hadits Imran Ibn Husain dari jalur Wahab Ibn Jarir dari Jarir dari Humaid Ibn Hilal dari Abu Qatadah dari Imran Ibn Husain dari Nabi Saw.

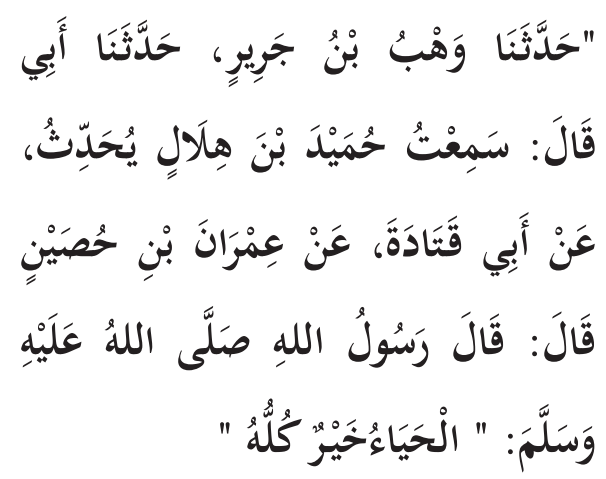

"Wahab Ibn Jarir menyampaikan hadits kepada kami, Bapakeku menyampaiakan badits kepada kami, ia berkata: aku mendengar Humaid ibn Hilal menyampikan hadits dari Abu Qatadah, dari Imran Husain. Ia berkata: Rasululallah Saw bersabda: semua sifat malu itu adalab baik"'. (HR Ahmad) (Ibn Hanbal, 2001: 210).

\section{Nilai-Nilai Sifat Malu}

Hadits yang diriwayatkan Imran Ibn Husain menerangkan penilaian Nabi Saw tentang sifat malu yang disebut sebagai sifat baik. Sifat seperti ini hendaknya dimiliki oleh setiap orang. Sebab, hal baik dapat dipastikan akan mendatangkan kebaikan pula. Hal ini dijelaskan pada hadits-hadits lain dari Nabi Saw yang menyebutkan bahwa perkara 
yang baik merupakan sesuatu yang diinginkan Allah Swt. Sebagaimana pada hadits dari Abu Hurairah:

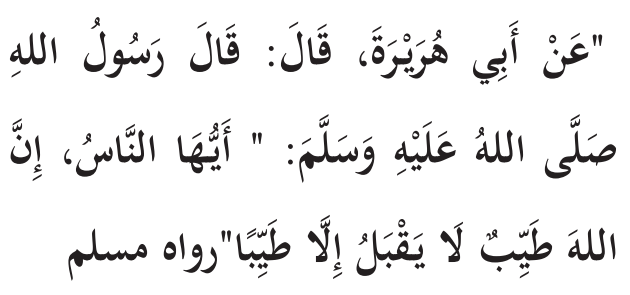

"Dari Abu Hurairah ra, ia berkata: telah bersabda Rasulullah Saw: wahai manusia sesunggunya Allah adalah rat yang baik, Allab tidak akan menrima sesuatu kecuali sesuatu yang baik pula". (HR Muslim). (AL-Qusyairi, t.th; 703).

Selain pada hadits Abu Hurairah, Nabi Saw menyebut semua jenis kebaikan akan membawa manusia ke dalam sorga. Sebagaimana hadits yang berasal dari Abdullah Ibn Mas'ud sebagai berikut:

\section{"عَنْ عَبْدِ اللهِ بْنِ مَسْعُودٍ قَالَ: قَالَ

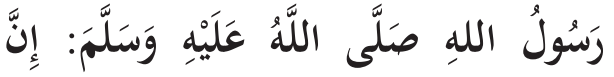

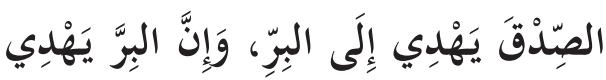

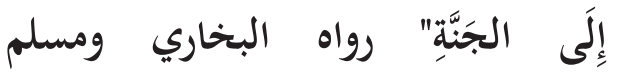 وابوداود والترمذي وابن ماجه}

"Dari Abdullah Ibn Mas'ud, ia berkata: telah bersabda Rasulullab Saw: Sesunggubnya kejujuran itu membawa ke arah kebaikan. Dan sesungguhnya kebaikan itu membawa ke arah sorga". (HR al-Bukhari, Muslim, Abu Dawud, Tirmizi dan Ibn Majah).”
Keterangan Nabi Saw tentang sifat malu ditegaskan kembali oleh Imran Ibn Husain saat ia mendengar seorang laki-laki yang bernama Busyair Ibn Ka'ab memberikan penjelasan sifat malu yang sumbernya berasal dari buku-buku hikmah. Menurut Busyair Ibn Ka'ab, sifat malu memilki unsur-unsur kebaikan seperti kehati-hataian dan ketenangan. Namun Busyair Ibn Ka'ab juga menyayangkan sifat malu itu dapat mendatangkan keburukan yaitu menyebabkan manusia menjadi sosok lemah. Mendengar pernyataan Busyair Ibn Ka'ab, maka Imran Husain menegurnya dengan sangat keras. Menurutnya, sifat malu merupakan salah satu sifat yang baik. Sementara kebaikan itu akan mempengaruhi segala hal dalam kehidupan manusia. Bahkan beliau menegaskan pernyataannya tersebut adalah suatu kabar yang bersumber dari Rasulullah Saw yang pasti kebenarannya. Maka, tidak pantas apabila ada orang yang berani menentang dan menyela apa yang dikabarkannya. Pernyataan Busyair Ibn Ka'ab itu tidak bisa dijadikan argumen yang kuat, sebab rujukan yang kuat adalah sesuatu yang berasal dari Rasulullah Saw. Beliau disebut dalam Al-Qur'an sebagai uswah hasanah yag berarti sumber tauladan baik bagi manusia.

Selain hanya sebagai sifat yang baik, sifat malu juga mengandung nilai-nilai positif yang mampu mendorong manusia agar menjadi manusia sejati. Hal itu antara lain:

1) Sifat malu dijelaskan oleh Rasulullah Saw sebagai salah satu usaha hamba dalam menghasilkan empat perkara yang terdiri dari 
kemampuan menjaga akal pikirannya, menjaga perutnya, selalu mengingat kematian dan meninggalkan perhiasan dunia (zuhud). Sebagaimana hadits dari Abdullah Ibn Mas'ud:

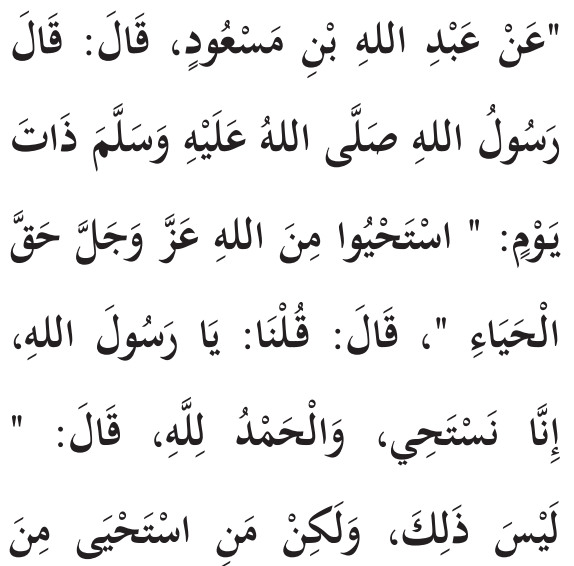

اللهِ حَقَّ الْحَيَاِِ، فَلْيَحْفَظِ الوَّأْسَ وَمَا

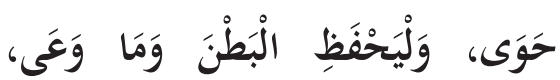

وَلْيَذْكُرِ الْمَوْتَ وَالْبْلَى، وَمَنْ أَرَادَ

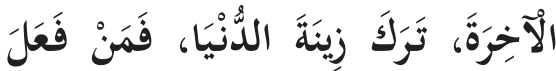

ذَلِكَكَ، فَقََدِ اسْتَحْيَا مِنَ اللِهِ عَزَّ وَجَلَّ حَقَّ الْحَيَاءِ "رواه أحمد

"Abdullah Ibn Masud, ia berkata: Pada suatu hari Rasulullah Saw bersabda: malulah Kalaian dari Allah dengan sebenar-benarnya. Berkata Abdullah: kami berkata: wahai Rasulullab sesungubnya kami malu, alhamdulillah. Beliau bersabda: malu itu bukan demikian. Namun siapa saja yang malu dari Allah dengan sebenar-benarnya maka bendaklah ia melindungi kepala dan isinya, jagalab perut dan isinya, mengingat kematian dan kehancurannya. Dan siapa saja menginginkan akbirat maka ia akan meninggalkan biasan dunia. Maka barangsiapa melakukan demikian sesungguhnya ia telah malu dari Alah azza wajalla dengan sebenarsebenarnya". (HR Ahmad)". (Ibn Hanbal, 2001: 187).

Hadits dari Abdullah Ibn Mas'ud menjelaskan hakikat sifat malu yang menurut Nabi Saw hendaknya memenuhi kreteria yaitu kemampuan menjaga akal pikirannya, menjaga perutnya, selalu mengingat kematian dan meninggalkan perhiasan dunia. Empat hal yang disampaikan Nabi Saw tersebut memberikan dampak positif dalam kehidupan manusia. Dalam segala perkataan dan perbuatan yang menjadi acuan hanyalah Allah Swt. Apabila keempat hal itu diabaikan maka menjadi penyebab manusia lupa diri dan menjauh dari Allah Swt. Karena itu, manusia akan berani melakukan maksiat sesuka hatinya tanpa ada rasa takut akibatnya dan tidak menyadari bahwa perbuatannya itu akan dimintai pertanggung jawaban Allah Swt.

2) Nabi Saw menjadikan sifat malu bagian dari iman yang merupakan masalah penting dalam usuluddin (pokok-pokok agama). Sebagaimana hadits dari Abdullah Ibn Umar sebagai berikut :

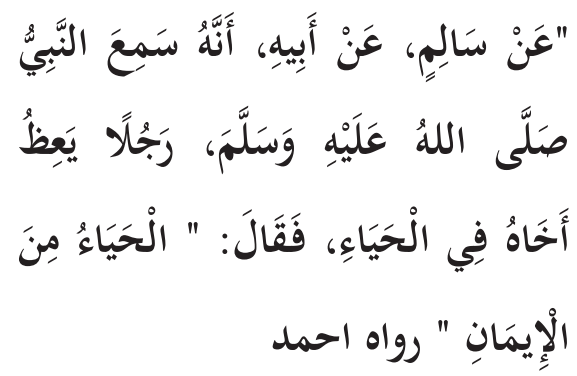


"Dari Salim dari bapaknya (Abdullah Ibn Umar) babwasannya Nabi Saw mendengar seorang laki-laki menasehati saudaranya tentang malu. Maka beliau bersabda: sifat malu bagian dari iman" (HR Ahmad). (Ibn Hanbal, 2001: 156)

Demikian pula pada hadits Abu Hurairah ra, Nabi Saw bersabda:

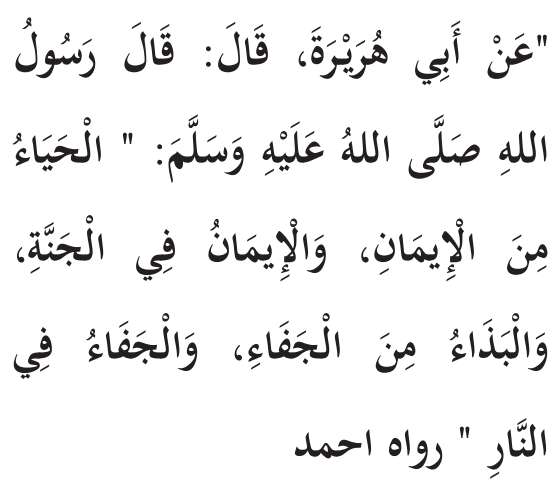

"Dari Abu Huraiarah ra, ia berkata: telah bersabda Rasulullah Saw: malu adalah bagaian dari iman dan iman itu adanya di dalam sorga. Pernyatataan yang buruk adalah bagian dari keras hati dan pernyataan keras itu adanya dalam neraka". (HR Ahmad). (Ibn Hanbal, 2001: 305).

Dimasukkannya sifat malu sebagai bagian dari iman menunjukkan bahwa pemilik sifat ini termasuk orang yang memiliki tanda-tanda keimanan yang sempurna. Dalam pandangan Ahlussunnah wa al-Jamaa'ah, iman selain sesuatu yang harus tertanam dalam hati juga dapat diaplikasikan dalam perbuatan sehari-hari. Sifat yang malu yang dicerminkan dalam perbuatan seorang manusia telah menandai dirinya sebagai salah seorang yang beriman. Iman tidak hanya sebatas angan-angan dan polesan belaka, namun juga harus disertai suatu pembuktian yaitu amal. Hal ini ditegaskan oleh al-Hasan alBashri dalam maqalah-nya yang masyhur tentang iman:

\section{كَيْسَ الْإِيمَانُ بِالتَّمَنِي، وَلَكِنْ مَا وَقَرَ فِي

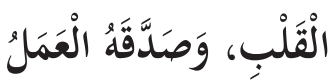

"Iman itu bukan hanya sekedar angan-angan, akan tetapi adalah sesuatu yang tertanam dalam hati dan dan dibuktikan oleh amal perbuatan" (Al-Andalusi, 1420H: 74) (AlHanbali, 1419H: 30).

3) Apabila pada hadits Abdullah Ibn Umar sifat malu merupakan bagian dari iman maka pada hadits lain Nabi Saw menyebutnya sebagai cabang iman. Sebagaimana hadits Abu Huraiarah ra:

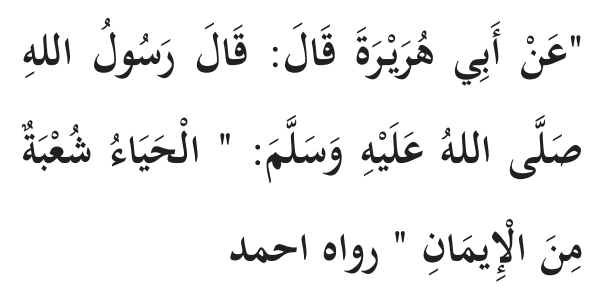

"Dari Abu Huraiarah ra, ia berkata: telah bersabda Rasulullah Saw: malu adalah cabang dari iman" (HR Ahmad) (Ibn Hanbal, 2001: 56).

Demikian pula pada hadits Ya'la Ibn Umayyah Nabi Saw bersabda: 


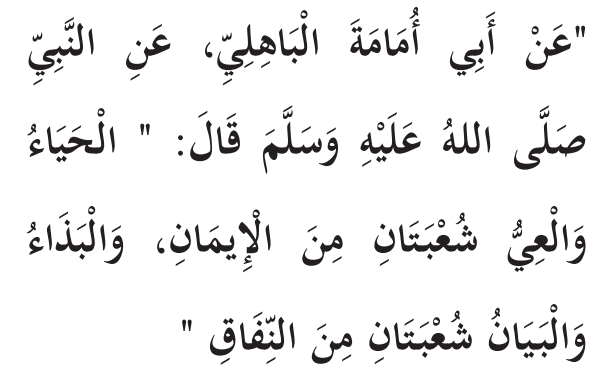

"Dari Abu Umamah al-Babili dari Nabi Saw bersabda: malu dan sedikit berbicara adalah cabang dari pada iman. Dan keburukan dan penjelasan yang berlebib-lebiban adalab dua cabanag dari kemunafikan" (HR Ahmad) (Ibn Hanbal, 2001: 649).

Penjelasan Nabi Saw yang memasukkan malu salah satu dari cabaang iman menyebabkan sifat malu menjadi salah satu bagian yang menyerupai pokok iman atau usul iman yang memiliki furu' atau cabang. Sebagaimana pengertian malu yang menempatkan malu salah satu pendorong manusia untuk melakukan hal-hal positif. Sifat malu tersebut memiliki furu' atau cabang yang banyak terdiri dari perkataan maupun perbuatan. Misalnya, malu jika dengki dan iri, malu untuk berbohong, dan malu apabila korupsi. Semua hal tersebut merupakan furu' atau cabang dari malu yang merupakan bagian dari iman juga. Maka dapat dikatakan pula malu merupakan sifat umum yang mencakup berbagai hal positif yang dapat dilakukan oleh manusia.

4) Sifat malu ibarat perhiasan yang dapat menghiasi dan mempercantik manusia, sebaliknya perbuatan buruk akan mengotori dan memperburuknya. Nabi Saw menjelaskan hal ini pada hadits Anas Ibn Malik:

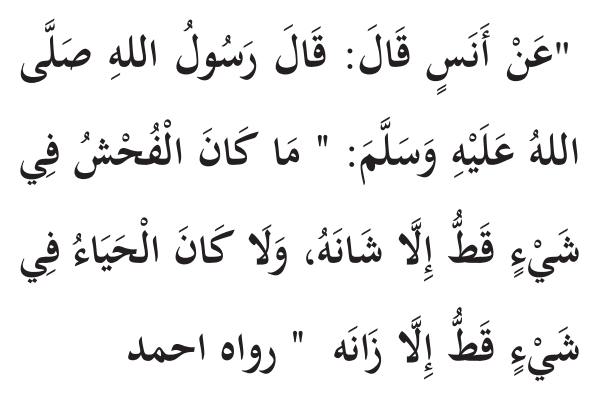

"Dari Anas, ia berkata: telah bersabda Rasulullah Saw: Tidak ada suatu keburukan berada dalam suatu perkara kecuali akan mengotori, dan tidak ada malu dalam suatu perkara kecuali akan menghiasinya" (HR Ahmad) (Ibn Hanbal, Jil. 20, 2001: 118).

Hadits ini menguatkan urgensi sifat malu yang menyebabkan manusia akan lebih menarik dan dipandang baik oleh orang lain terutama oleh Allah Swt yang menyaksikan gerak-gerik manusia tersebut setiap harinya. Demikian pula dalam pergaulan, manusia yang bergaul dengannya akan menyenangi pergaulannya dan akan berusaha pergaulannya itu dirawat dengan baik. Lebih dari itu, sifat malu itu akan membekas pada kawannya dengan perbuatanperbuatan positif dan bertanggung jawab.

5) Sifat malu merupakan salah satu sifat yang dicintai Allah Swt, sebagaimana hadits dari Abu Ya'la ra: 


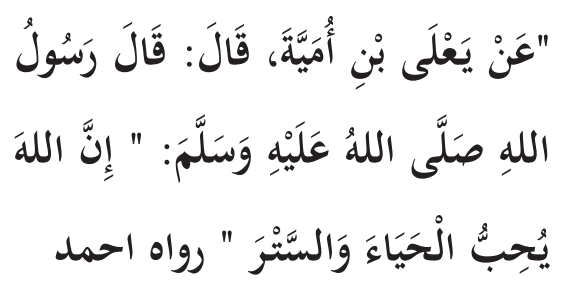

"Dari Ya'la Ibn Umayyah, ia berkata: telah bersabda Rasulullah Saw: sesunggubnya Allab mencintai malu dan tertutup" (HR Ahmad) (Ibn Hanbal, Jil. 29, 2001: 483).

Setiap manusia yang salih menginginkan dirinya selalu dicintai Allah Swt. Salah satu cara untuk mendapatkan cinta Allah Swt adalah malu. Apabila Allah telah mencintai seorang hamba maka Allah akan memberikan keistimewan kepada hamba tersebut. Di antara keistimewaan tersebut adalah:

1) Allah mengurus dan merawatnya sejak masa kanak-kanak

2) Allah menancapkan keimanan pada hati hamba yang dicintainya

3) Akalnya mendapatkan nur (cahaya) dari Allah Swt

4) Melaksanakan semua yang diperintahkan Allah

5) Allah Swt memberikan kemudahan pada hambanya

6) Peribadinya mendapatkan arahan dari Allah dengan baik secara lahir maupun batin (Al-Maqdisi, 1398H: 349).

\section{PENUTUP}

Hadits Imran Ibn Husain adalah salah satu hadits yang penting diketahui oleh setiap muslim. Pada hadits tersebut, Nabi Saw menggolongkan malu salah satu sifat yang baik pada manusia. Penjelasan Nabi Saw tersebut merupakan jawaban kepada orangorang yang masih memiliki anggapan bahwa malu adalah sifat buruk yang mesti ditinggalkan.

Penjelasan sifat malu yang ada pada hadits Imran Ibn Husain ditegaskan lagi oleh hadits-hadits Nabi Saw lainnya. Pada hadits-hadits tersebut diterangkan bahwa sifat malu dapat berkontribusi dalam pendidikan antara lain: 1) Pendidikan malu dapat memupuk kemampuan manusia dalam menjaga akal pikiran; 2) Menjauhkan perbuatan untuk mengonsumsi hal-hal yang dilarang; 3) Selalu mengingat kematian; 4) Menjadi peribadi yang zubud; 5) Berkontribusi dalam pendidikan pendidikan iman; 6) Pendidikan untuk menghias dan mempercantik diri dengan sifat terpuji yaitu malu; 7) Pendidikan manusia untuk mencapai cinta Allah Swt. 


\section{DAFTAR PUSTAKA}

Al-Andalusi, Abu Hayyan Muhammad Ibn Yusuf Ibn Hayyan Asir ad-Din, 1420H, al-Babr al-Mubit, Beirut: Dar al-Fikr

Al-Asqalani, Ahmad Ibn Ali Ibn Hajar, t.th, Fath al-Bari Syarb Sabih al-Bukhari, (Beirut:Dar al-Ma'rifah, t.th).

Al-Bukhari, Muhammad Ibn Ismail, 1422

$\mathrm{H}$, Sahih al-Bukhari, Damaskus: Turuq an-Najah

Al-Fairuz Abadi, Majd ad-Din Abu Tahir Muhammad Ibn Ya'kub, 1426H, al-Qamus al-Mubit, Beirut: Muassah ar-Risalah

Al-Hanbali, Abu Hafs Siraj ad-Din Umar Ibn Ali Ibn Adil, 1419H, al-Lubab fi Ulum al-Kitab, Beirut: Dar alKutub al-Ilmiyyah

Al-Jauziyyah, Muhammad Ibn Abu Bakar

Ibn Sa'd Syams ad-Din Ibn Qayyim, 1416 H, Madarij asSalikin baina Manazil Iyyaka Na'budu wa Iyyaka Nastain, Beirut: Dar al-Kitab al-Arabi

Al-Maqdisi, Najm ad-Din Abu al-Abbas Ahmad Ibn Abdurrahman, 1398H, Mukbtasar Minhaj alQaidin, Damaskus: Makatabah Dar al-Bayan

Al-Muqaddam, Muhammad Ibn Ismail, 1436 H, Fiqh al-Haya, Mesir: alAmal

Al-Qazwini, Ibn Majah Abu Abdillah Ibn Muhammad Ibn Yazid, t.th, Sunan Ibn Majah, Beirut: Dar Ihya alKutub al-Arabi

Al-Qusyairi, Muslim Ibn al-Hajjaj, t. th, Sabih Muslim, Beirut: Ihya Turas al-Arabi

An-Nawawi, Abu Zakarya Yahya Ibn Syaraf, 1415H, al-Minhaj Syarb Sahih Muslim Ibn al-Hajjaj, Beirut: Dar al-Ma'rifah
Asy-Syafi'i, Muhammad Ali Ibn Muhammad al-Bakri, 1425H, Dalil al-falibin li Turuq Riyad asSalihin, Beirut: Dar al-Ma'rifah

At-Tirmidzi, Muhammad Ibn Isa Ibn Saurah, 1998, Sunan at-Tirmizi, Beirut:Dar al-Garb al-Islami

At-Tirmidzi, Muhammad Ibn Isa Ibn Saurah, 1998, Sunan at-Tirmizi, Beirut: Dar al-Garb al-Islami

Az-Zamil, Abd al-Muhsin Ibn Abdullah, t.th, Syarb Hadits Syu'ab al-Iman, https://www.alukah.net/web/.di akses 12 Agustus 2019.

Ermayani, Tri, 2017, LGBT dalam Prespektif Islam, Jurnal Humnika, Th XXVII, No. $\quad$ 1September 2017 (https://www.reasearchgate.net) diakses 16 Juli 2019

Ibn Al-Asyas, Abu Dawud Sulaiman, t.th, Sunan Abu Dawnd, Beirut:alMaktabah al-Asriyyah

Ibn Hanbal, Ahmad, 2001, al-Musnad, Beirut:Muassah ar-Risalah

Sumsel Tribun News.com, diakses 16 juli 2019. 